\title{
Prospects for the Economy and Society? The Issue of Employability and the Implementation of Inquiry-Based Learning
}

\author{
Karsten Speck and Wilfried Schubarth
}

In this article, we intend to examine the contribution that inquiry-based learning makes to the economy and society based on the report by Schubarth and Speck (2013). We will examine (a) stakeholder interests in the economy, higher education and society, (b) the importance of inquiry-based learning in higher education policy and (c) the implementation of appropriate research and practical offers in institutions of higher learning.

\subsection{Participant Interests in Higher Education Policy and Economy/Society}

Over the course of the Bologna Process, the term "employability" has become increasingly central to the harmonization of European university education and the common university framework. An important milestone for the further development of the higher education system was the 1999 Bologna Declaration, which called for the introduction of comparable qualifications in Europe, and which justified the need for the employability of European citizens and the international competitiveness of the European higher education system (Bologna-Declaration 1999, p. 3). The German version of the Bologna-declaration (Bologna-Erklärung 1999) refers to "promoting the mobility and labor-market qualification of its citizens" and emphasizes the need for comparable degrees in order to "qualify

\footnotetext{
K. Speck, Prof. Dr. (ه)

Carl von Ossietzky Universität Oldenburg, Fakultät Bildungs- und Sozialwissenschaften, Institut für Pädagogik, Forschungsmethoden in den Erziehungs- und Bildungswissenschaften, Oldenburg, Germany e-mail: karsten.speck@uni-oldenburg.de

W. Schubarth, Prof. Dr.

Universität Potsdam, Department Bildungswissenschaften, Professur für Erziehungs- und Sozialisationstheorien, Potsdam, Germany

e-mail: wilschub@uni-potsdam.de
}

H. A. Mieg (ed.), Inquiry-Based Learning - Undergraduate Research, https://doi.org/10.1007/978-3-030-14223-0_37 
the labor market relevant qualifications of European citizens as well as the international competitiveness of the European higher education system to promote it" (BolognaErklärung 1999, p. 2 et seq., translated).

In its 1999 decision on the "Akkreditierung von Studiengängen mit den Abschlüssen Bachelor und Master" ("Accreditation of degree programs with the bachelor's and master's degrees"), the German Accreditation Council, which is responsible for quality assurance in the course of studies and in teaching in Germany by means of an accreditation of degree programs, formulated numerous minimum standards for the accreditation of degree programs (Akkreditierungsrat 1999). The requirements were a practical application or practical relevance of the course of study, as well as the employability or professional qualification of the university graduates. Accreditation procedures should "help to increase student mobility and improve international recognition of degrees" (ibid., p. 1). The accreditation agencies should take into consideration the "educational function of the degree program, and the likelihood that the degree can be completed within the projected number of terms, in particular in terms of the employability of the graduates and foreseeable developments in possible professional fields" (ibid., p. 2, translated).

The German Science Council (Wissenschaftsrat), which advises the German federal government and state governments, has been regularly and extensively engaged in recent years with (a) the employability of graduates and (b) the relationship between university education and the labor market. In 1999, for example, the German Science Council called for a stronger "discussion by institution of higher learning about problems in development, imparting of knowledge and preservation of employability" (Wissenschaftsrat 1999, p. 5). In 2000, the German Science Council defined three basic goals of academic study: "intellectual development through scholarship, scholarly based employability and the personal development of students" (Wissenschaftsrat 2000, p. 21). In the recommendations on the relationship between a university education and the labor market, the German Science Council assumes that the institutions of higher learning can contribute to the future safeguarding of the potential of skilled workers by "encouraging students to acquire skills-relevant competencies" and promote a broad university education (Wissenschaftsrat 2015, p. 9, translated).

The German Rector's Conference (Hochschulrektorenkonferenz, HRK) has dealt with the relationship between academic education and the labor market in many statements. It calls, inter alia, for (a) the further development of study contents with a view to better employability and a stronger integration of interdisciplinary and profession-related competencies in the study (HRK 2005), (b) institutions of higher learning to embrace socializing, action-oriented and character-forming functions, and to promote professional qualification among graduates by imparting key competencies and integrating vocationalfield-oriented internships (HRK 2008); and (c) sensitivity on the part of institutions of higher learning for labor market/practice requirements and non-academic or interdisciplinary key qualifications, as well as an implementation of the labor marketability/employability expected by the study reform (HRK 2009).

The Federal Society of the German Employer Associations (BDA) has been involved in university policy for many years and criticizes the lack of practical training. The BDA 
advocates stronger practice orientation in degree programs (e.g. through internships, project-based and problem-based learning) and labor market-related degree programs (BDA 2014, p. 1). In the interest of employability, in a joint memorandum, the BDA, the HRK and the Federation of German Industry (BDI) have called on the institutions of higher learning to: (a) prepare students for a professional occupation in addition to social participation; (b) to apply technical content and methods in the degree programs, (c) to relate the study contents to fields of practice and, at the same time, to impart interdisciplinary and key competencies, (d) to support the development of scientific and labor marketrelevant competencies during the course of studies and (e) to impart professional, methodological, social and personal competencies within the degree programs (BDA/ HRK/BDI 2008, p. 6 et seq.).

The German Chamber of Commerce and Industry (DIHK) has already interviewed several companies about university graduates. The current survey reveals that, above all, companies expect graduates to exhibit a capacity for teamwork (B.A.: 72\%; M.A.: 57\%), the ability to work independently/self-manage (B.A.: 68\%; M.A.: 66\%) as well as an ability to analyze and make decisions (B.A.: 67\%; M.A.: 68\%) (DIHK 2015, pp. 10 and 17). The companies express the expectation (among others) that study material will be more application-oriented and that internships will be more integrated within degree programs (DIHK 2015, pp. 9 and 15). In a 2012 statement, the Chief Human Resource Officers at Leading German Companies also criticized the lack of practice orientation and practical relevance in university study. They advocated for greater practical relevance, longer practice phases of at least 3 months, and the integration of internships into curricula (Personalvorstände führender deutscher Unternehmen, 2012). At the same time, they emphasize the importance of interdisciplinary competencies: "Companies primarily hire well-educated individuals and not formal degrees" (ibid., p. 3, translated).

\subsection{The Significance of Inquiry-Based Learning in Higher Education Policy}

Parallel to the Bologna Process, inquiry-based learning has gained increased significance at institutions of higher learning, in publications and at conferences (Reiber 2007; Journal Hochschuldidaktik 2009; Ramm et al. 2014). Crucial for this are likely the demands for a professional qualification (B.A.) or a research-oriented degree (M.A.), the increasing research orientation and a third-party orientation in the institutions of higher learning, the limits of traditional teaching in the face of changing learning styles and the lack of compulsory attendance of students, as well as promoting relevant projects through the Teaching Quality Pact.

Compared to employability, inquiry-based learning has thus far only been afforded marginal importance in statements on university policy from the political arena, scientific organizations and employers. In addition to the handouts and conferences of the HRK, the German Science Council (Wissenschaftsrat) in particular has positioned itself repeatedly and in an interdisciplinary manner as being for inquiry-based learning in recent years: 
- In 2006, the German Science Council (Wissenschaftsrat) emphasized the special importance of inquiry-based learning for later employment: University education can qualify someone to perform a qualified activity "if, in addition to imparting a constantly renewed canon of knowledge, it aims primarily at proficiency, developing questions independently, dealing systematically with problems, obtaining knowledge in a methodological manner and critically reflecting on fundamental questions" (Wissenschaftsrat 2006, p. 64, translated).

- In a 2008 recommendation, the Science Council noted that insufficient consideration had been given to inquiry-based learning during the reform processes and in teaching and study programs: "The implementation of this approach requires the additional and hitherto unfamiliar measures of counseling, guidance and structuring, but also a new, more binding relationship required between teachers and learners. [...] Teaching and study courses often do not focus on inquiry-based learning to the necessary extent" (Wissenschaftsrat 2008, p. 23, translated).

- In the current recommendations on the relationship between university education and the labor market (2015), the German Science Council (Wissenschaftsrat) points out that, more and more, institutions of higher learning are trying to increase the relevance of their study programs for the labor market (e.g. by means of innovative teaching and learning formats such as inquiry-based learning). Institutions of higher learning have been prompted to further expand inquiry-based learning (Wissenschaftsrat 2015, p. 14). In inquiry-based learning, the German Science Council recognizes "a promising approach that can foster the development of labor market relevant competencies that are relevant for the labor market, especially if it orients itself to practice-relevant issues, and at the same time picks up on the idea of "education through scholarship"" (ibid., p. 12, translated).

\subsection{Implementation of Employability and Inquiry-Based Learning}

Finally, the question arises as to what the promotion of employability and the implementation of inquiry-based learning in Germany actually looks like. Due to the focus on other questions, the student survey provides no clear answers; however, it does provide empirical evidence. For example, in the survey, students were asked about practice-relevant and research-related courses offered within their degree programs (Ramm et al. 2014, p. 262 et seq., last updated: 2012/2013 winter semester):

Courses with a Practical Orientation According to the survey, practical relevance is offered less frequently at universities and more frequently at universities of applied sciences. For example, from a student's point of view, practical lectures (19\% of universities vs. $34 \%$ of universities of applied sciences), courses on practicing practical activities (16\% of universities vs. $23 \%$ of universities of applied sciences) and practice-oriented projects (13\% of universities vs. $28 \%$ of universities of applied sciences) are offered to differing 
degrees in the degree programs. In view of the strong desire for practical relevance in the course of studies, however, a relatively large number of students are not informed about practical offers or deny that such offers exist in their degree programs. The practical relevance and vocational preparation are assessed very differently by the students at universities and universities of applied sciences: At the universities, $21 \%$ of students perceive a close practical relevance and $12 \%$ a good job preparation in their field of study. All the same, at the universities of applied sciences at least, 59\% of students confirm a close practical relevance and $35 \%$ confirm good job preparation in their field of study.

Research-Related Courses At the universities, only $11 \%$ of students indicate that there are many courses dealing with teaching/learning research or (research-related) project seminars. $32 \%$ of students confirm there are few, and $17 \%$ confirm there are no courses dealing with teaching/learning research or project seminars. At any rate, $40 \%$ of the students do not know whether there are such courses at the universities. The situation is similar at the universities of applied sciences: $12 \%$ of students state that there are many courses dealing with teaching/learning research or (research-related) project seminars. $32 \%$ of students indicate there are few, and $21 \%$ indicate there are no courses dealing with teaching/learning research or project seminars. $35 \%$ of students at universities of applied sciences are not informed about whether there are such courses in their degree program. The findings also show: At the beginning of the course of study, there is less research relevance and significantly more students are uninformed about corresponding offers. At the universities, $31 \%$ of students attest that their field of study has a strong research orientation in the teaching; at the universities of applied sciences, this is a little less, at $22 \%$. In addition, it has been noticeable that there has been a distinct increase in the research orientation at universities and universities of applied sciences in recent years.

\subsection{Summary}

It has been shown that the employability of graduates, and a practical and labor-marketrelevant education oriented towards such employability, are given a high priority in many statements from higher education policy, scientific organizations and employers. It is also undisputed that, in addition to a practical and labor-market-relevant education in the interests of the economy, institutions of higher learning must also provide a basic academic, technical university education and interdisciplinary personal development (citizenship). Thus, a comprehensive university assignment aims at teaching or acquiring (1) an academic, technical university education, (2) a practical and labor market relevant (education) and (3) interdisciplinary personal development.

In principle, inquiry-based learning offers the opportunity to contribute to this comprehensive university mission. So far, however, inquiry-based learning is more of a marginal topic in higher education policy. The German Science Council, which, in addition to the German Rector's Conference, has dealt more intensively with the topic, considers inquirybased learning to be a particularly suitable teaching and learning format for fostering labor 
market-relevant competencies and "education through scholarship" (Bildung durch Wissenschaft, e.g. independent development of questions, systematic engagement with problems, obtaining knowledge in a methodological manner, critically reflecting on fundamental questions), since students are actively involved here and an exemplary scientific cognitive process is reproduced. In summary, inquiry-based learning can (still) be established as a problem of meaning in university politics, a problem of theory, a problem of legitimacy and a problem of implementation in Germany (Box 37.1).

\section{Box 37.1: Effects of Inquiry-Based Learning. Discussions on Practice-Relevant Transfer Competencies, Spring/Summer 2015 (Andrea Augsten)}

The question is whether those proficiencies, which are promoted through inquirybased learning in a course of study, are already noticeable in corporate practice. Below are excerpts from four interviews.

Moritz Gekeler worked as a futurologist at Daimler AG, as a lecturer and program manager at the HPI School of Design Thinking and as a design strategist at the SAP Design and Co-Innovation Center. At present, he heads the consulting firm DOLABORATE GmbH.

Angela Haas is a human-centered design expert at Swisscom AG and works on the interface between design and management. She is interested in design thinking in business management, among other things.

Ruth Lassalle is a senior consultant at HRpepper Management Consultants and teaches at Basel University. As a psychologist, she has many years of experience in change and development projects as well as in the field of personnel diagnostics and development.

Andrea Schröter has been the head of HR at Leifheit AG (Nassau/Lahn) since the end of 2012. As a lawyer, she has previously worked for the BASF Group and most recently as director of Global Human Resources at Tridonic GmbH \& Co KG (Dornbirn/Austria).

\section{What kind of people do you tend to hire?}

Andrea Schröter: For me it is crucial to hire thinking people, regardless of whether this is scientific thinking, philosophical thinking, or both. It is crucial that newcomers to the profession form their opinions independently and freely. We need to get away from an anticipatory obedience and retain independent thinking people, and the autonomy and cognitive freedom in the mind of inquiry-based learning is very good for doing so.

Ruth Lasalle: The handling of complexity and analytical thinking is indispensable in the innovation environment. Career beginners in particular need a high tolerance for dealing with uncertainties and the ability to adapt to an organization and its 


\section{Box 37.1 (continued)}

culture. This can be associated with an intrinsically motivated, questioning attitude. Overall, however, it is questionable whether this ability is promoted solely through inquiry-based learning. In my view, getting to know different contexts and situations is especially important in order to be able to take different perspectives.

Moritz Gekeler: People with excellent expertise and, at the same time, an inquisitive gaze beyond the boundaries of their own discipline; that's exactly what we are looking for. Designing futures requires skills in possibility spaces, dealing with fuzzy goals, and an empathic capacity for communication in order to overcome the boundaries of terminology and personal assumptions.

Angela Haas: The chemistry has to be right. Applicants must be able to think in context and apply facts, insights and behaviors to other areas. This transfer is crucial and it gets noticed!

How important is it to be proficient in communication and teamwork? Does it help to have conducted research yourself?

Angela Haas: It always requires that ability and desire interact with one another. This fundamental idea shapes collaboration in multidisciplinary teams as the basis for innovation. Something new comes out when designers combine their proficiencies with other disciplines; here, designers are often more affine. Within the context of design and research, I see parallels: Both are looking for something new. This can offer added value, especially in interdisciplinary collaboration.

Moritz Gekeler: There are some parallels, but there are differences between scientists and designers: Scientists form hypotheses and try to substantiate or prove them. Designers, on the other hand, constantly design new hypotheses in the design process and design iteratively. If they have this freedom, they use it more intensively than pure scientists, because they want to cut to the chase more.

Ruth Lasalle: In my experience almost every applicant describes themselves as a particularly good team player. That is why it is important to check this in selection situations. Selection procedures which include interviews with situational questions as well as simulations such as role-plays have proven to be successful. For goal-oriented communication, the ability to bring things to the point, as well as developing a sense of what information my counterpart needs, is very important.

Andrea Schröter: We are currently actively working on setting up and integrating teams in which employees from different areas can work together. We want to transform our existing, functional organization into a flexible, drifting structure with project-based teams, at least in part in order to stay competitive. For our young people, this is no problem at all, but with older people, it is necessary to deliberately overstep the boundaries of the department. Career starters do not defend their "territory," but instead see their task, find it exciting, and actively approach people whose proficiencies they need for that task, whether in the company cafeteria or in the parking lot. Inquiry-based learning offers the opportunity to train your own signature (individuality and self-determination). 


\section{References}

Akkreditierungsrat (1999). Akkreditierung von Akkreditierungsagenturen und Akkreditierung von Studiengängen mit den Abschlüssen Bachelor/Bakkalaureus und Master/Magister Mindeststandards und Kriterien. Retrieved 29 November 2015 from http://ids.hof.uni-halle.de/ documents/t564.htm

Bologna-Declaration (1999). The Bologna Declaration. Joint declaration of the European ministers of Education. Retrieved 29 November 2015 from http://www.ond.vlaanderen.be/hogeronderwijs/bologna/documents/mdc/bologna_declaration1.pdf

Bologna-Erklärung (1999). Der Europäische Hochschulraum. Gemeinsame Erklärung der Europäischen Bildungsminister. Retrieved 29 November 2015 from http://portal.tugraz.at/portal/ page/portal/Files/International/files/formulare_broschueren/Bologna_Erklaerung.pdf

Bundesvereinigung der Deutschen Arbeitgeberverbände (BDA) (2014). kompakt. Hochschulpolitik. Retrieved 29 November 2015 from http://www.arbeitgeber.de/www\%5Carbeitgeber.nsf/res/ kompakt-Hochschulpolitik.pdf/\$file/kompakt-Hochschulpolitik.pdf

Bundesvereinigung der Deutschen Arbeitgeberverbände/Bundesverband der Deutschen Industrie \& Hochschulrektorenkonferenz (BDA/BDI/HRK) (2008). Bildung schafft Zukunft. Beschäftigungsfähigkeit von Hochschulabsolventen stärken. Für eine bessere Arbeitsmarktrelevanz des Hochschulstudiums. Berlin. Retrieved 29 November 2015 from http:// www.arbeitgeber.de/www\%5Carbeitgeber.nsf/res/72374EDE418466EBC125755A004AC403/\$ file/Beschaeftigungsfaehigkeit_Hochschulabsolventen.pdf

Deutscher Industrie- und Handelskammertag (DIHK) (2015). Kompetent und praxisnah Erwartungen der Wirtschaft an Hochschulabsolventen. Ergebnisse einer DIHK OnlineUnternehmensbefragung. Berlin/Brüssel. Retrieved 29 November 2015 from http://www. dihk.de/ressourcen/downloads/dihk-umfrage-hochschulabsolventen-2015.pdf/at_download/ file?mdate $=1433751323077$

Hochschulrektorenkonferenz (HRK) (2005). Empfehlung zur Sicherung der Qualität von Studium und Lehre in Bachelor- und Masterstudiengängen. Retrieved 29 November 2015 from www.hrk. de/uploads/tx_szconvention/Beschluss_Kapazitaeten.pdf

Hochschulrektorenkonferenz (HRK) (2008). Bologna-Reader III. FAQs-Häufig gestellte Fragen zum Bologna-Prozess an deutschen Hochschulen. Bologna-Zentrum. Beiträge zur Hochschulpolitik 8/2008. Bonn Retrieved 29 November 2015 from http://hrk.de/fileadmin/redaktion/hrk/02Dokumente/02-10-Publikationsdatenbank/Beitr-2008-08_BolognaReader_III_FAQs.pdf

Hochschulrektorenkonferenz (HRK) (2009). Neue Anforderungen an die Lehre in Bachelor- und Master-Studiengängen. Jahrestagung des HRK Bologna-Zentrums. Beiträge zur Hochschulpolitik 1/2009. Retrieved 29 November 2015 from http://www.hrk-bologna.de/bologna/de/download/ dateien/5._Aufl._final.pdf

Journal Hochschuldidaktik (2009). Forschendes lernen: Perspektiven eines Konzepts. 20 (2).

Personalvorstände führender deutscher Unternehmen (2012). Bologna@Germany 2012. 5. Erklärung der Personalvorstände führender deutscher Unternehmen. Retrieved 29 November 2015 from http://www.arbeitgeber.de/www/arbeitgeber.nsf/res/Bologna@Germany2012. pdf/\$file/Bologna@Germany2012.pdf

Ramm, M./Multrus, F./Bargel, T./Schmidt, M. (2014). Studiensituation und studentische Orientierungen. 12.Studierendensurvey an Universitäten und Fachhochschulen. Berlin: BMBF-Eigendruck.

Reiber, K. (2007). Grundlegung: Forschendes Lernen als Leitprinzip zeitgemäßer Hochschulbildung. Tübinger Beiträge zur Hochschuldidaktik, 1(3). Retrieved 29 November 2015 from http://tobiaslib.uni-tuebingen.de/volltexte/2007/2924/ 
Schubarth, W./Speck, K. (2013). Employability und Praxisbezïge im wissenschaftlichen Studium. HRK-Fachgutachten (ausgearbeitet für die HRK, unter Mitarbeit von Juliane Ulbricht, Ines Dudziak und Brigitta Zylla). Retrieved 29 November 2015 from http://www.hrk-nexus.de/fileadmin/redaktion/hrk-nexus/07-Downloads/07-02-Publikationen/Fachgutachten_Employability.pdf

Wissenschaftsrat (1999). Stellungnahme zum Verhältnis von Hochschulausbildung und Beschäftigungssystem. Retrieved 29 November 2015 from http://www.wissenschaftsrat.de/ download/archiv/4099-99.pdf

Wissenschaftsrat (2000). Empfehlungen zur Einführung neuer Studienstrukturen und -abschlüsse (Bakkalaureus/Bachelor - Magister/Master) in Deutschland. Retrieved 29 November 2015 from http://www.wissenschaftsrat.de/download/archiv/4418-00.pdf

Wissenschaftsrat (2006). Empfehlungen zur künftigen Rolle der Universitäten im Wissenschaftssystem. Retrieved 29 November 2015 from www.wissenschaftsrat.de/download/ archiv/7067-06.pdf

Wissenschaftsrat (2008). Empfehlungen zur Qualitätsverbesserung von Lehre und Studium. Retrieved 29 November 2015 from http://www.wissenschaftsrat.de/download/archiv/8639-08. pdf

Wissenschaftsrat (2015). Empfehlungen zum Verhältnis von Hochschulbildung und Arbeitsmarkt. Retrieved 29 November 2015 from www.wissenschaftsrat.de/download/archiv/4925-15.pdf

Open Access This chapter is licensed under the terms of the Creative Commons AttributionNonCommercial-NoDerivatives 4.0 International License (http://creativecommons.org/licenses/bync-nd/4.0/), which permits any noncommercial use, sharing, distribution and reproduction in any medium or format, as long as you give appropriate credit to the original author(s) and the source, provide a link to the Creative Commons licence and indicate if you modified the licensed material. You do not have permission under this license to share adapted material derived from this chapter or parts of it.

The images or other third party material in this chapter are included in the chapter's Creative Commons licence, unless indicated otherwise in a credit line to the material. If material is not included in the chapter's Creative Commons licence and your intended use is not permitted by statutory regulation or exceeds the permitted use, you will need to obtain permission directly from the copyright holder.

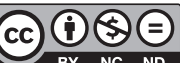

